\title{
Community study of dragon's blood palm (Daemonorops spp.) in Harapan Rainforest, Sumatra
}

\author{
REVIS ASRA $^{1, \bullet}$, JOKO RIDHO WITONO ${ }^{2}$, IZUANDRY FIJRIDIYANTO ${ }^{2}$, ELVA $^{3}$, STEFAN SCHEU \\ ${ }^{1}$ Biology Department, Faculty of Science dan Technology, Universitas Jambi. Jl. Jambi-Muara Bulian Km. 15. Kampung Pinang Masak, Mendalo Darat, \\ Muaro Jambi 36361, Jambi, Indonesia. Tel.: +62-741-583377, •email: revisasra@unja.ac.id \\ ${ }^{2}$ Research Center for Plant Conservation Bogor Botanic Gardens, Indonesia Institute of Sciences. Jl. Ir. H. Juanda No. 13 Bogor 16022, West Java, \\ Indonesia \\ ${ }^{3}$ Harapan Rain Forest, Jambi, Indonesia \\ ${ }^{4}$ J.F. Blumenbach Institute of Zoology and Anthropology, Georg August University, Göttingen, Germany
}

Manuscript received: 20 August 2019. Revision accepted: 21 November 2019.

\begin{abstract}
Asra R, Witono JR, Fijridiyanto I, Elva, Scheu S. 2019. Community study of dragon's blood palm (Daemonorops spp.) in Harapan Rainforest, Sumatra. Biodiversitas 20: 3632-3640. Dragon's blood palms are rattan species that produce red-colored exudate on its fruit skin, popularly called exudates 'dragon's blood'. It has a high economic value and plays an important role as an income source for indigenous tribes in Jambi, such as in Bukit Duabelas National Park who live Anak Dalam Tribe and Semerantihan Village live Talang Mamak Tribe. However, overexploitation and unsustainable harvesting method have caused its decline in its population in natural forest. This study aims to make an inventory and map distribution of Dragon's blood palms in Harapan Rainforest, at the boundary between Jambi and South Sumatra Provinces, Indonesia; to determine its sex ratio and identify environmental factors that influence sex of Dragon's blood palms. This research used purposive random sampling method at three areas in Harapan Rainforest, i.e.: Hamparan Bato, Hamparan Batang Kapas, and Hamparan between Block A and B. The results showed that three species of Daemonorops were found in Harapan Rainforest, namely Daemonorops didymophylla, D. draco, and D. longipes. D. longipes has the highest population (18 clumps). The highest number of clumps were found in Hamparan Bato (17 clumps)and Hamparan Batang Kapas (17 clumps) areas. The ratio of male and female plants of $D$. longipes is $1: 1.84$, D. draco is $1: 2$ and D. didymophylla is $2.2: 1$. Most clumps of Daemonorops species in Harapan Rainforest grow on the river banks which have low organic matters. Soil chemical variables that most contribute to the growth of Daemonorops spp. in Harapan Forest are N, C and pH.
\end{abstract}

Keyword: Distribution, Daemonorops, Harapan rainforest, rattans, sex ratio

\section{INTRODUCTION}

Dragon's blood palms belong to the Daemonorops group of clump rattans. The name Dragon's blood refers to red resinous exudate collected from the fruits of the genus Daemonorops, mainly from Indonesian Islands. Locally called Jernang or Djerang, these species are ecologically, economically, medicinally, and industrially beneficial plants. This is evidenced by the results of a survey regarding the selling price of red exudate in Jambi Province which during 2009-2012 reached Rp. 800,000 / kg (Asra et al. 2012) and in 2015 it had reached 3-4 million rupiahs. Ecologically, these plants have an important role in maintaining forest sustainability, especially at river borders. They require trees to climb and stay upright for reaching the sunlight, and they grow on the riverbank areas. As these plants produce economically important red exudates which is known as Dragon's blood, these plants are hence important for the income for indigenous tribes and local communities who live around the forest in Sumatra exudate. The red exudate was harvested from unripe fruit and it has a high price in the markets (Asra et al. 2014; Sulasmi et al. 2012a). This exudate has been used in industry by pharmaceutical companies for various types of diseases. This exudate's functions are to increases blood circulation, reduces pain, increases tissue regeneration, sprains, ulcers, diarrhea, anti-tumor, anti-viral and hair coloring. One species of Dragon's blood palm that produces the highest red exudate is Daemonorops draco (Piozzi et al. 1974; Pearson 2002; Cavallo et al. 2008, Thomson 2007; Gupta et al. 2007; Mairida et al. 2016).

Indonesia is the biggest exporter of dragon's blood in the world while China demand for the same is around 400500 tons per year. However, there is declining trend in its production and the populations of dragon's blood palms in natural forest are becoming rare (Balai Informasi Kehutanan Provinsi Jambi 2009), mainly due to illegal logging and encroachment for oil palm plantations and rubber plantations (Sulasmi et al. 2012a; Sulasmi et al. $2012 b)$. Therefore, conservation efforts to protect the parent trees and planting of $D$. draco and the other species of Daemonorops are essential.

Forest Ecosystem Restoration (Harapan Rainforest) is an area suitable for conservation activities of dragon's blood palms. Ecosystem restoration is an effort to rebuild the presumed structure, productivity and diversity of the forest which originally existed in that area. Thus, forest restoration is a deliberate activity to help accelerates the recovery of an ecosystem in connection with the alleged historical composition, structure, function, productivity and 
biodiversity of species from an ecosystem in a location (Ciccarese et al. 2012). This is in accordance with the mission of the Harapan Rainforest, at the boundary between Jambi and South Sumatra Provinces, Indonesia: to protect and restore the biodiversity, ecosystem service and production of Indonesia's natural forest. The study was conducted with goals: (i) to make inventory and distribution mapping of Dragon's blood palms in Harapan Rainforest, (ii) to determine its sex ratio and environmental factors that influence sex of Dragon's blood palms.

\section{MATERIALS AND METHODS}

\section{Study sites}

Harapan Rainforest is the first ecosystem restoration concession established in Indonesia. It is located in Sumatra Island, at the boundary between Jambi and South Sumatra Provinces, Indonesia (Figure 2). It covers an area of about 101.355 ha of ex-logging concession forests. The site is managed by PT. Restorasi Ekosistem Indonesia (PT. REKI), a private company and Yayasan Konservasi Ekosistem Hutan Indonesia (Yayasan KEHI) a non-governmental organization, having a 100-yr license to manage this area. Harapan Rainforest represents an important opportunity for demonstrating the potential of ecosystem restoration as a viable land-use option for Indonesia's logged-over forests (Harrison and Swinfield 2012).

\section{Methods}

Survey and data collection in this study were carried out using the purposive random sampling method at three areas of Harapan Rainforest (Hamparan Bato, Hamparan Batang Kapas, and Hamparan between Block A and Block B). The identification of the collected Daemonorops spp. from those areas were based on comparison with the specimens preserved at Herbarium Bogoriense, Research Center for Biology, Indonesian Institute of Sciences, Cibinong, Indonesia. The distribution of the Daemonorops spp. Were marked with Garmin ETrex 10 GPS SEA. Identification of male and female plants was done based on morphological observations of the inflorescence using binocular. Sex ratios were calculated using vates corrected chi-square $\left(\chi^{2}\right)$ (Snedecor dan Cochran 1989) to check whether they match with the theoretical 1: 1 ratio or not. $\chi^{2}$ values were calculated in MS Excel, while probability of $\chi^{2}$ was obtained from the distribution function 1-pchisq of Stats package in $\mathrm{R}$ ( $\mathrm{R}$ Core Team 2018). One individual (seedling) of D. longipes was excluded from the analysis due to its juvenility. The growth levels of clumps were divided into four categories: youngest $(<3 \mathrm{~m})$, young $(3-5$ $\mathrm{m})$, mature $(5-15 \mathrm{~m})$ and aged $(>15 \mathrm{~m})$. The habitat features of the Daemonorops spp. growing sites include depth of roots, soil texture, ground color, slope, etc. Ground color codes are based on Munsell Color Chart. Soil samples were analyzed in the Soil Laboratory of the Faculty of Agriculture, Jambi University. Chemical soil parameters ( $\mathrm{pH}, \mathrm{Al}-\mathrm{dd}, \mathrm{H}-\mathrm{dd}, \mathrm{CEC}, \mathrm{C} \%, \mathrm{~N} \%$, and $\mathrm{P}$ ) were analyzed in Principal Component Analisis (PCA) using Minitab statistical software.

\section{RESULTS AND DISCUSSION}

\section{Inventory and distribution of Daemonorops species in Harapan Rainforest}

According to Waluyo (2012) and Asra (2013), the Dragon's blood-producing species of Daemonorops reported from Jambi Province include Jernang burung (Daemonorops didymophylla Becc.), Jernang umbut (D. melanochaetes Blume.), Jernang kalamuai (D. longipes Mart.), Jernang rambai (D. draco (Willd.) Blume) and Jernang kepala puyuh (Daemonorops sp.). The current study revealed there were three species and total of 43 of Daemonorops found in Harapan Rainforest, namely $D$. didymophylla (16 clumps), D. draco (9 clumps) and $D$. longipes (18 clumps) which is also the most common species found in Harapan Rainforest (Figure 1).

Sulasmi et al. (2012b) reported 10 species of Daemonorops from the Province of Jambi namely $D$. brachystachys, $D$. didymophylla, D. dracuncula, $D$. dransfieldii, D. longipes, $D$. palembanica, $D$. singalana, $D$. trichroa, D. draco, and D. mattanensis (=D. didymophylla). The current study reveals the presence of 3 species of Daemonorops in the Harapan Rainforest area namely $D$. draco, D. didymophylla, and D. longipes, all of which produce red exudate called dragon's blood. However, $D$. draco is most sought after Daemonorops for the Dragon's blood as its panicle could reach up to $1 \mathrm{~m}$ in length and weigh up to $20 \mathrm{~kg}$ Waluyo (2013), whereas other species could have panicle length of only about $30 \mathrm{~cm}$.

Species distribution of each Daemonorops in Hamparan Bato, Hamparan Batang Kapas, and Hamparan (between block A and B) areas in Harapan Rainforest are depicted in Figure 2. It was noted that all three areas had presence of the three species of Daemonorops studied. However, unlike Hamparan Bato and Hamparan Batang Kapas which showed male and female clumps of the mentioned three species of Daemonorops and also had their high concentration (17 clumps in each area). Hamparan (between block A and B) area not only had low concentration (9 clumps) but also did not have representation of male clumps of $D$. didymophylla.

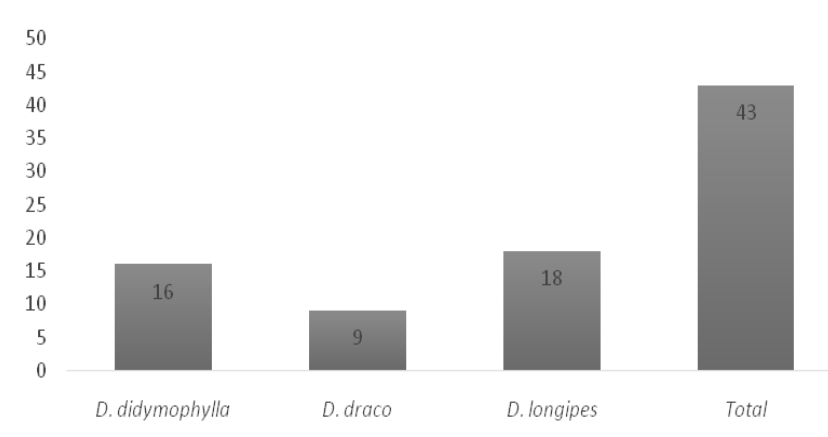

Figure 1. The species of Daemonorops and number of its clumps found in Harapan Rainforest 

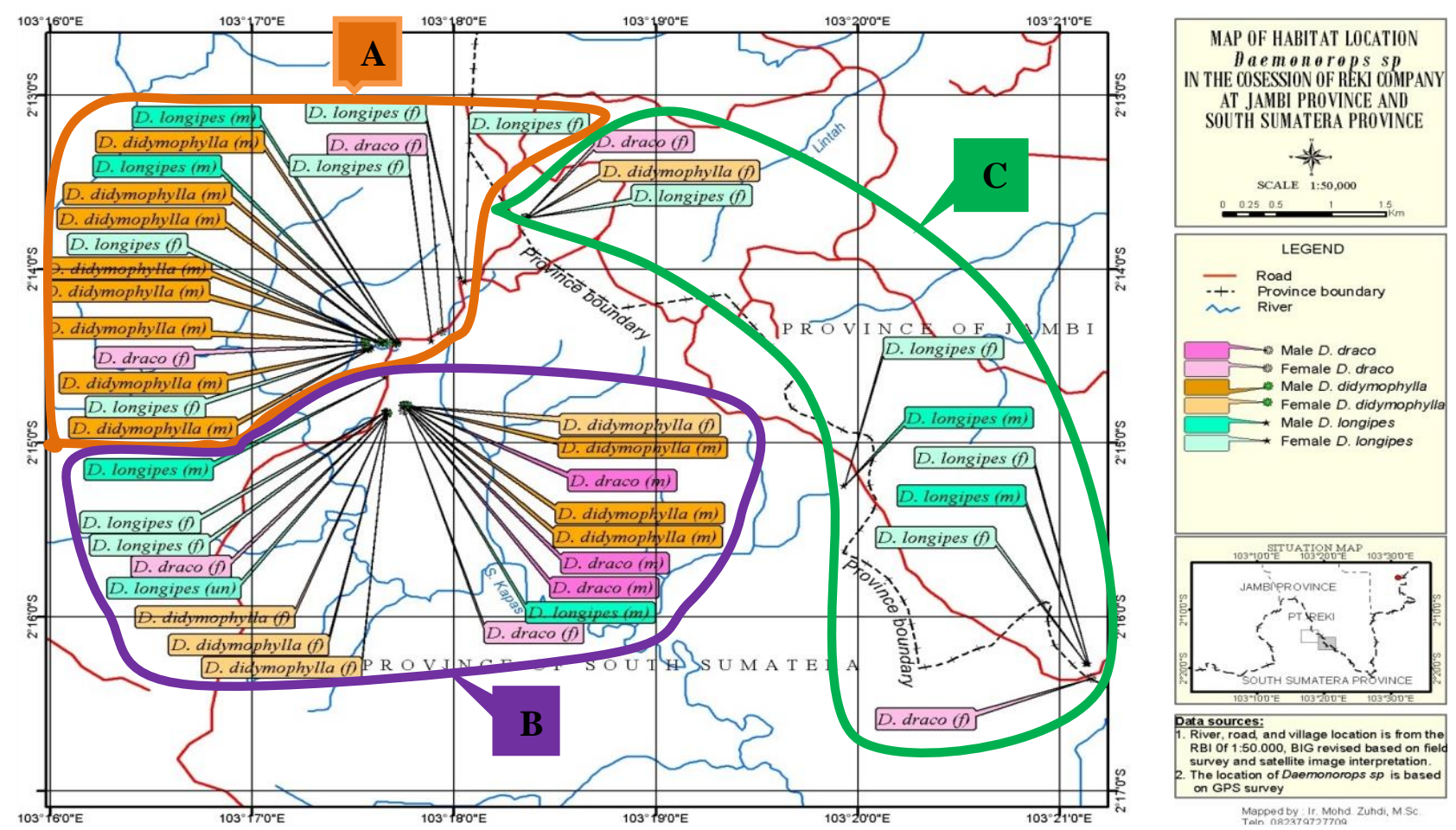

Figure 2. Species distribution map of Daemonorops spp.in Harapan Rainforest, at the boundary between Jambi and South Sumatra Provinces, Indonesia (A. HamparanBato, B. HamparanBatangKapas, C. Hamparan between Block A and B)

\section{The growth structure of Daemonorops spp. found in Harapan Rainforest}

Figure 3 shows the growth structure of the three species of Daemonorops found in the Harapan Rainforest during study. It clearly shows that the number of youngest individuals base on the length of the individuals within a clump $(<3 \mathrm{~m})$ had the number of frequencies among the studies clumps, followed by mature individuals $(5-15 \mathrm{~m})$. Among the three species, D. longipes has the highest representation of both youngest, mature and aged individuals. However, all species showed low number of young individuals $(3-5 \mathrm{~m})$.

In general, it seemed that all the species relatively had adequate number of mature individuals in Harapan rainforest which are essential to maintain their continuum of progenies. The high number of youngest individuals are also suggestive of the good regenerative capacity of Daemonorops spp. in the Harapan Rainforest.

\section{Plant association of Daemonorops species in Harapan Rainforest}

Being a liana, Daemonorops species in Harapan Rainforest depend very much on the supporting trees for climbing up to get sunlight (Sulasmi 2012b). It is reported that they require as much as 3-4 individual trees for support (Sulasmi 2012 b), and the figure of 4 individual trees has also been corroborated by the study of which (Soemarna 2009). However, it is also stated by the later's study that Daemonorops doesn't specifically are dependent upon particular tree species and the loss/decline in the number of supporting trees would also negatively impact the population of Daemonorops spp.

From the current study, it was found that Daemonorops longipes has the highest number of plant association (29 species and 25 families), followed by $D$. didymophylla (16 species and 12 families) and D. draco (15 species and 13 families) (Figure 4). The most common trees found associated with Dragon's blood palms were Thotteacorymbosa, Psychotriasp, Uvaria sp., Bhesapani culata, Dacryodes rostrata, Gynotroches axillaris, Nephellium cuspidatum, Palaquium sumatranum. However, no species had particular preference for particular tree species, and interestingly the three species of Daemonorops did not share any common tree species.

\section{Sex ratio of Daemonorops species in Harapan \\ Rainforest}

In Harapan Rainforest, the sex ratio of male and female plants of Daemonorops didymophylla were found to be 2.2: $1, D$. draco to be 1: 2 while $D$. longipes showed sex ratio of 1: 1.84. In general, female plants had the highest population than male plants except for Daemonorops didymophylla where male plant population was the highest. Sex ratio of dioecious plants in natural populations is expected to be 1: 1 (Rottenberg 2000). However, the biases of sex ratios have been reported in natural population for male-biased (Dupont and Kato 1999) and female-biased (Stehlik and Barret 2005). 
Table 1. Association of Daemonorops species with other plants plants in Harapan Rainforest

\begin{tabular}{|c|c|c|c|}
\hline Species & Plants association & Family & Freq. \\
\hline \multirow{16}{*}{$\begin{array}{l}\text { Daemonorops } \\
\text { didymophylla }\end{array}$} & Albizia myriophylla & Leguminosae & 1 \\
\hline & Alseodaphne sp. & Lauraceae & 1 \\
\hline & Canarium sp. & Burseraceae & 1 \\
\hline & Cissus repens & Vitaceae & 1 \\
\hline & Clidemia hirta & Melastomataceae & 1 \\
\hline & Dacryodes sp. & Burseraceae & 1 \\
\hline & Dillenia obovata & Dilleniaceae & 1 \\
\hline & Macaranga hosei & Euphorbiaceae & 1 \\
\hline & Macaranga trichocarpa & Euphorbiaceae & 1 \\
\hline & Psychotria sp & Rubiaceae & 1 \\
\hline & Pternandra caerulescens & Melastomataceae & 1 \\
\hline & Selaginella sp. & Selaginellaceae & 1 \\
\hline & Syzygium lineatum & Myrtaceae & 1 \\
\hline & Tetracera indica & Dilleniaceae & 1 \\
\hline & Thottea corymbosa & Aristolochiaceae & 1 \\
\hline & Uvaria sp. & Annonaceae & 1 \\
\hline \multirow{15}{*}{$\begin{array}{l}\text { Daemonorops } \\
\text { draco }\end{array}$} & Dysoxylum sp. & Meliaceae & 1 \\
\hline & Hopea sangal & Dipterocarpaceae & 1 \\
\hline & Knema sp. & Myristicaceae & 1 \\
\hline & Lasiantus sp. & Rubiaceae & 1 \\
\hline & Macaranga sp. & Euphorbiaceae & 1 \\
\hline & Nephelium uncinatum & Sapindaceae & 1 \\
\hline & Ochanostachys amentacea & Olacaceae & 1 \\
\hline & Orania sp. & Arecaceae & 1 \\
\hline & Psychotria sp. & Rubiaceae & 1 \\
\hline & Scaphium macropodum & Malvaceae & 1 \\
\hline & Shorea leprosula & Dipterocarpaceae & 1 \\
\hline & Sterculiasp. & Malvaceae & 1 \\
\hline & Syzygium cauliflorum & Myrtaceae & 1 \\
\hline & Xanthophyllum sp. & Polygalaceae & 1 \\
\hline & Ziziphus sp. & Rhamnaceae & 1 \\
\hline \multirow{29}{*}{$\begin{array}{l}\text { Daemonorops } \\
\text { longipes }\end{array}$} & Artabotryssp. & Annonaceae & 1 \\
\hline & Barringtonia sp. & Lecythidaceae & 1 \\
\hline & Bellucia pentamera & Melastomataceae & 3 \\
\hline & Bhesa paniculata & Centroplacaceae & 2 \\
\hline & Bridelia glauca & Phyllanthaceae & 1 \\
\hline & Callicarpa pentandra & Lamiaceae & 1 \\
\hline & Cissus nodosa & Vitaceae & 1 \\
\hline & Dacryodes rostrata & Burseraceae & 2 \\
\hline & Dialium indum & Leguminosae & 1 \\
\hline & Elaeocarpus sp. & Elaeocarpaceae & 1 \\
\hline & Garcinia parvifolia & Clusiaceae & 1 \\
\hline & Gironniera nervosa & Cannabaceae & 1 \\
\hline & Gironniera subaequalis & Cannabaceae & 1 \\
\hline & Gynotroches axillaris & Rhizophoraceae & 2 \\
\hline & Ixonanthes icosandra & Ixonanthaceae & 1 \\
\hline & Knema laurina & Myristicaceae & 1 \\
\hline & Lithocarpus sp. & Fagaceae & 1 \\
\hline & Litsea sp. & Lauraceae & 1 \\
\hline & Macaranga bancana & Euphorbiaceae & 1 \\
\hline & Macaranga hosei & Euphorbiaceae & 1 \\
\hline & Mussaenda frondosa & Rubiaceae & 1 \\
\hline & Nephellium cuspidatum & Sapindaceae & 1 \\
\hline & Palaquium sumatranum & Sapotaceae & 1 \\
\hline & Pandanus sp. & Pandanaceae & 1 \\
\hline & Parkia speciosa & Leguminosae & 1 \\
\hline & Rhodamnia cinerea & Myrtaceae & 1 \\
\hline & Sterculia rubiginosa & Malvaceae & 1 \\
\hline & Syzygium sp. & Myrtaceae & 1 \\
\hline & Uvaria $\mathrm{sp}$. & Annonaceae & 1 \\
\hline
\end{tabular}

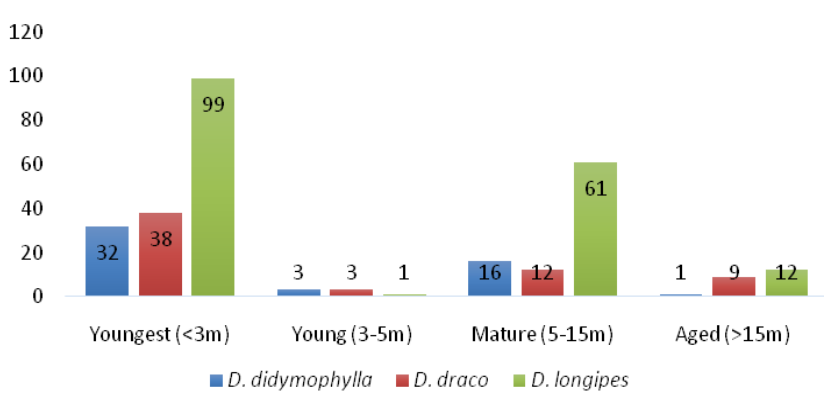

Figure 3. Growth levels of individuals of Daemonorops species found in Harapan Rainforest

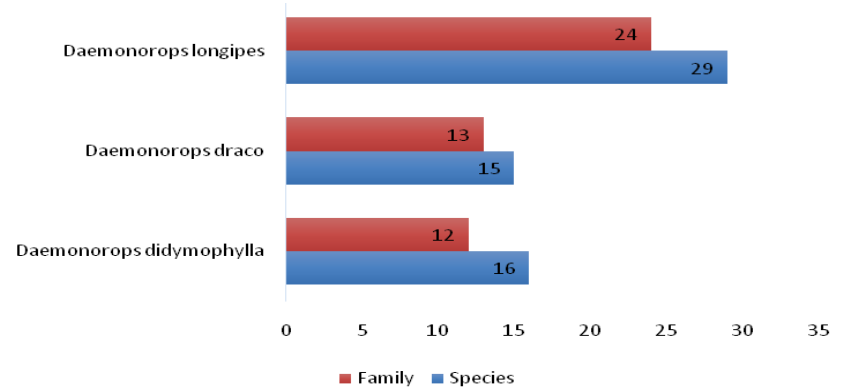

Figure 4. Number of plant species and families associated with Daemonorops spp. in Harapan Rainforest

According to Lee (1995) environmental conditions also affect sex expression of dragon's blood palms. Under favorable conditions, female sex expression is reported to increase, while under unfavourable conditions increased, male sex expression have been noted.

For identifying the significance of the observed deviation of sex ratio yates corrected chi-square $\left(\chi^{2}\right)$ method was applied and it was observed that the values of $\chi^{2}$ for $D$. didymophylla male was $0.783(\mathrm{P}=0.376)$ and female was $1.531(\mathrm{P}=0.216)$ totaling the $\chi^{2}$ value to 2.314 $(\mathrm{P}=0.128)$; the values of $\chi^{2}$ for $D$. draco male was 0.888 $(\mathrm{P}=0.346)$ and female was $0.222(\mathrm{P}=0.638)$ totaling the $\chi^{2}$ value to $1.11(\mathrm{P}=0.29)$; while the $\chi^{2}$ values for $D$. longipes male was $1.058(\mathrm{P}=0.304)$ and female was 0.470 $(\mathrm{P}=0.493)$ totaling the $\chi^{2}$ value to $1.528(\mathrm{P}=0.216)($ Table 2 ). For 1 degree of freedom the $\chi^{2}$ values fell short of statistical significance leading to the understanding that the deviations in sex ratios are either due to chance and it cannot be established on regional study basis, or the sampling needs to be conducted in wider area as well as correlate the sex ratios with range of environmental factors.

Data from Table 2 shows that $D$. didymophylla had more individual male plants than individual female plants, but for $D$. draco and $D$. longipes had more individual female plants rather than individual male plants. Average number of individual male plants of $D$. longipes $10.33 \pm$ 7.87 per individual, while for individual female plants is $10,00 \pm 6.03$ individuals/clump. In D. draco, average number for individual male plant is $6.33 \pm 5.51$ and individual female plant is $7.17 \pm 3.60$ individuals/clump. $D$. didymophylla has an average number of individual male plant is $2.64 \pm 2.06$ and female plant is $4.60 \pm 4.62$ individuals/clump (Table 3 ). 
The environmental effect on the gender of Daemonorops species in Harapan Rainforest

It was found that the male plants of $D$. didymophylla and D. longipes prefers riverbanks, therefore preliminary results suggest that the males of the above two species prefer habitat that has higher water content and slightly inundated areas than the female counterparts.

Table 4 shows that the male plants of $D$. didymophylla habitat are near the riverbank, so that ecologically the male plants like a habitat that has a high water content than females. From the soil texture, there is one of the male plants which has a rusty that is at a depth of $27 \mathrm{~cm}$ and the color of yellow soil at a depth of $20-60 \mathrm{~cm}$ which shows the soil is less fertile.

Soil fertility is the ability of soil to provide nutrients needed by plants to support growth and reproduction. Nutrients in the form of nutrients can be absorbed by plants through roots (Hardjowigeno 2007). Based on the data from the soil analysis above, it can be said that the soil fertility level in Harapan REKI forest is physically medium, and the growth limiting factor in addition to its rather steep topography is also the effective depth of the soil which is rather shallow. So that the soil fertility level is maintained, soil conservation measures are very important, given the steep topography conditions with high rainfall and high rainfall intensity, very vulnerable to erosion. Soil conservation techniques can be carried out biologically, namely by planting woody plants at the top or with agroforestry systems and other woody plants with high economic value at the bottom that borders community lands that function as buffer zones from disturbances to the forest. In regional areas that have rather steep and extreme slopes, swales or terraces should be made as a barrier to erosion (Yamani 2010).

In both tables, male plants of $D$. longipes and $D$. didymophylla, mostly found around the river. So it can be concluded that both species are mostly found on the riverbank or in the inundated areas. According to Soemarna (2009), the species grows on Red Yellow Podsolic (PMK) soil types, in the lowlands, and acidic soil $\mathrm{pH}$ ranges from 4-6, rainfall ranges from 1000-2300 $\mathrm{mm}$, air temperature ranges from $24-32^{\circ} \mathrm{C}$, humidity ranges $60-85 \%$. Therefore, maximum cultivation will be obtained when maximum results are carried out in their natural habitat. Based on the opinion of Soemarna (2009), the Suku Anak Dalam forest area in Jambi is a suitable habitat for the Dragon's blood palm development area.

Table 2.Observed sex ratios of three species of Daemonorops found in Harapan Rainforest and the vates corrected chi-square $\left(\chi^{2}\right)$ statistics. $\left(\mathrm{O}_{\mathrm{male}}\right)=$ Observed male clumps, $\left(\mathrm{O}_{\text {female }}\right)=$ Observed female clumps, $\left(\mathrm{E}_{\mathrm{male}}\right)=$ Expected male clumps, $($ Efemale $)=$ Expected female clumps.

\begin{tabular}{lccccccccc}
\hline \multicolumn{1}{c}{ Species } & $\left(\mathbf{O}_{\text {male }}\right)$ & $\left(\mathbf{O}_{\text {female }}\right)$ & $\begin{array}{c}\text { Total } \\
\text { clumps }\end{array}$ & $\left(\mathbf{E}_{\text {male }}\right)$ & $\left(\mathbf{E}_{\text {female }}\right)$ & $\begin{array}{c}\text { Sex } \\
\text { ratio }\end{array}$ & $\begin{array}{c}\left(\left[\mathbf{O}_{\text {male }}-\mathbf{E}_{\text {male }}\right]-\right. \\
\mathbf{0 . 5})^{2} / \mathbf{E}_{\text {male }}\end{array}$ & $\begin{array}{c}\left(\left[\mathbf{O}_{\text {female }}-\mathbf{E}_{\text {female }}\right]-\right. \\
\mathbf{0 . 5})^{2} / \mathbf{E}_{\text {female }}\end{array}$ & $\begin{array}{c}\text { Total } \\
\boldsymbol{\chi}^{2}\end{array}$ \\
\hline D. didymophylla & 11 & 5 & 16 & 8 & 8 & $2.2: 1$ & 0.783 & 1.531 & 2.314 \\
D. draco & 3 & 6 & 9 & 4.5 & 4.5 & $1: 2$ & 0.888 & 0.222 & 1.11 \\
D. longipes & 6 & 11 & 17 & 8.5 & 8.5 & $1: 1.84$ & 1.058 & 0.470 & 1.528 \\
\hline
\end{tabular}

Table 3. Comparison of number of male and female individuals of Daemonorops species found in Harapan Rainforest

\begin{tabular}{lccc}
\hline \multicolumn{1}{c}{ Species } & Local name & $\begin{array}{c}\text { Average no.of male } \\
\text { individuals/clumps }\end{array}$ & $\begin{array}{c}\text { Average no. of female } \\
\text { individuals/clumps }\end{array}$ \\
\hline Daemonorops didymophylla & Jernang burung & $2.64 \pm 2.06$ & $4.60 \pm 4.62$ \\
Daemonorops draco & Jernang rambai & $6.33 \pm 5.51$ & $7.17 \pm 3.60$ \\
Daemonorops longipes & Jernangkalamuai & $10.33 \pm 7.87$ & $10.00 \pm 6.03$ \\
\hline
\end{tabular}

Table 4. Description of soil from Daemonorops didymophylla

\begin{tabular}{|c|c|c|c|}
\hline \multirow{2}{*}{ Description of soil } & \multicolumn{3}{|c|}{ D. didymophylla } \\
\hline & Male (J7) & Male (J10) & Female (J2) \\
\hline Depth of roots & $>80 \mathrm{~cm}$ & $>80 \mathrm{~cm}$ & $>80 \mathrm{~cm}$ \\
\hline \multirow[t]{3}{*}{ Soil texture } & $0-5 \mathrm{~cm}=$ litter & $0-8 \mathrm{~cm}=$ upper layer; & $0-5 \mathrm{~cm}=$ litter \\
\hline & $0-12 \mathrm{~cm}=$ organic matter; & $40-60 \mathrm{~cm}=$ sandy clay; & $5-15 \mathrm{~cm}=$ organic matter; \\
\hline & $\begin{array}{l}0-13 \mathrm{~cm}=\text { upper layer } \\
0-20 \mathrm{~cm}=\text { clay }\end{array}$ & $27 \mathrm{~cm}=$ rusty depth & $15-80 \mathrm{~cm}=$ lower layer \\
\hline \multirow[t]{3}{*}{ Ground color } & $0-13 \mathrm{~cm}=10 \mathrm{yr} 4 / 6 \mathrm{dyb}$ & $0-5 \mathrm{~cm}=10 \mathrm{yr} 4 / 6 \mathrm{dyb}$ & $0-15 \mathrm{~cm}=10 \mathrm{yr} 4 / 6 \mathrm{dyb}$ \\
\hline & $14-30 \mathrm{~cm}=10 \mathrm{yr} 5 / 4 \mathrm{yb}$ & $6-20 \mathrm{~cm}=10 \mathrm{yr} 6 / 8$ by; & $15-40 \mathrm{~cm}=10 \mathrm{yr} 6 / 8$ by; \\
\hline & $30-60 \mathrm{~cm}=10 \mathrm{yr} 5 / 8 \mathrm{yb}$ & $20-60 \mathrm{~cm}=10 \mathrm{yr} 7 / 8 \mathrm{y}$ & $30-80 \mathrm{~cm}=10 \mathrm{yr} 6 / 8$ by \\
\hline \multirow[t]{4}{*}{ Slope } & upper $3^{\circ}$ & upper $3^{\circ}$ & upper $17^{\circ}$ \\
\hline & lower $4^{\circ}$ & lower $4^{\circ}$ & lower $21^{\circ}$ \\
\hline & right side $4^{\circ}$; & right side $4^{\circ}$; & right side $9^{\circ}$ \\
\hline & left side $4^{\circ}$ & left side $4^{\circ}$ & left side $7^{\circ}$ \\
\hline Habitat & Riverbank & Riverbank & Middle of the hill \\
\hline
\end{tabular}


Table 5. Description of soil from Daemonorops draco

\begin{tabular}{lll}
\hline \multirow{2}{*}{ Description of soil } & \multicolumn{1}{c}{ D. draco } \\
\cline { 2 - 3 } Depth of roots & Female $(\mathbf{J 1})$ & Female $(\mathbf{J 2 1})$ \\
Soil texture & $0-5 \mathrm{~cm}=$ litter; & $>60 \mathrm{~cm}$ \\
& $5-15 \mathrm{~cm}=$ organic matter; & $0-5 \mathrm{~cm}=$ litter; \\
& $15-80 \mathrm{~cm}=$ lower/transition layer & $0-27 \mathrm{~cm}=$ upper layer; transition layer on the lower; \\
Ground color & $0-15 \mathrm{~cm}=10 \mathrm{yr} 4 / 6 \mathrm{dyb} ;$ & $10-20 \mathrm{~cm}=$ contain charcoal \\
& $15-30 \mathrm{~cm}=10 \mathrm{yr} 6 / 8 \mathrm{by} ;$ & $0-10 \mathrm{~cm}=10 \mathrm{yr} 4 / 3 \mathrm{db} ;$ \\
& $30-80 \mathrm{~cm}=10 \mathrm{yr} 6 / 8$ by & $10-20 \mathrm{~cm}=10 \mathrm{yr} 4 / 6 \mathrm{dyb} ;$ \\
Slope & & $20-30 \mathrm{~cm}=10 \mathrm{yr} 5 / 8 \mathrm{yb} ;$ \\
& upper $19^{\circ} ;$ & $30-60 \mathrm{~cm}=10 \mathrm{yr} 6 / 8 \mathrm{by}$ \\
& lower $12^{\circ} ;$ & upper $19^{\circ} ;$ \\
Habitat & right side $6^{\circ} ;$ & lower $11^{\circ} ;$ \\
\hline
\end{tabular}

Table 6. Description of soil from Daemonorops longipes

\begin{tabular}{|c|c|c|c|c|}
\hline \multirow{2}{*}{$\begin{array}{l}\text { Description } \\
\text { of soil }\end{array}$} & \multicolumn{4}{|c|}{ D. longipes } \\
\hline & Male (J16) & Male (J20) & Female (J3) & Female (J27) \\
\hline Depth of roots & $>80 \mathrm{~cm}$ & $>60 \mathrm{~cm}$ & $>60 \mathrm{~cm}$ & $>60 \mathrm{~cm}$ \\
\hline Soil texture & $\begin{array}{l}0-3 \mathrm{~cm}=\text { litter; } \\
0-20 \mathrm{~cm}=\text { upper layer }\end{array}$ & $\begin{array}{l}0-7 \mathrm{~cm}=\text { litter } \\
0-23 \mathrm{~cm}=\text { upper layer } \\
20-30 \mathrm{~cm}=\text { litter; } \\
40-60 \mathrm{~cm}=\text { sandy clay }\end{array}$ & $\begin{array}{l}0-5 \mathrm{~cm}=\text { litter; } \\
0-20 \mathrm{~cm}=\text { upper layer/organic } \\
\text { matter; } \\
30-60 \mathrm{~cm}=\text { transition layer }\end{array}$ & $\begin{array}{l}0-6 \mathrm{~cm}=\text { litter; } \\
0-27 \mathrm{~cm}=\text { upper layer; } \\
0-20 \mathrm{~cm}=\text { sandy clay } \\
30-60 \mathrm{~cm}=\text { dusty sand soil }\end{array}$ \\
\hline Ground color & $\begin{array}{l}0-15 \mathrm{~cm}=10 \mathrm{yr} 4 / 6 \mathrm{dyb} \\
15-40 \mathrm{~cm}=10 \mathrm{yr} 6 / 8 \mathrm{by} \\
30-80 \mathrm{~cm}=10 \mathrm{yr} 6 / 8 \text { by }\end{array}$ & $\begin{array}{l}0-20 \mathrm{~cm}=10 \mathrm{yr} 5 / 6 \mathrm{yb} ; \\
20-30 \mathrm{~cm}=10 \mathrm{yr} 4 / 6 \mathrm{dyb} ; \\
30-60 \mathrm{~cm}=10 \mathrm{yr} 6 / 8 \mathrm{by}\end{array}$ & $\begin{array}{l}0-15 \mathrm{~cm}=10 \mathrm{yr} 4 / 6 \mathrm{dyb} \\
15-35 \mathrm{~cm}=10 \mathrm{yr} 5 / 8 \mathrm{yb} \\
36-60 \mathrm{~cm}=10 \mathrm{yr} 6 / 8 \mathrm{by}\end{array}$ & $\begin{array}{l}0-7 \mathrm{~cm}=10 \mathrm{yr} 4 / 3 \mathrm{db} \\
8-27 \mathrm{~cm}=10 \mathrm{yr} 4 / 6 \mathrm{dyb} \\
28-50 \mathrm{~cm}=10 \mathrm{yr} 6 / 8 \mathrm{by} \\
51-80 \mathrm{~cm}=10 \mathrm{yr} 7 / 8 \mathrm{y}\end{array}$ \\
\hline Slope & $\begin{array}{l}\text { upper } 9^{\circ} ; \\
\text { lower } 12^{\circ} ; \\
\text { right side } 2^{\circ} \\
\text { left side } 2^{\circ}\end{array}$ & $\begin{array}{l}\text { upper } 17^{\circ} ; \\
\text { lower } 5^{\circ} ; \\
\text { right side } 2^{\circ} \text {; } \\
\text { left side } 3^{\circ}\end{array}$ & $\begin{array}{l}\text { upper } 17^{\circ} ; \\
\text { lower } 20^{\circ} ; \\
\text { right side } 6^{\circ} \\
\text { left side } 10^{\circ}\end{array}$ & $\begin{array}{l}\text { upper } 7^{\circ} \\
\text { lowerh } 4^{\mathrm{o}} \\
\text { right side } 1^{\mathrm{o}} \\
\text { left side } 2^{\circ}\end{array}$ \\
\hline Habitat & Riverbank & Riverbank & Hilltop & Slope \\
\hline
\end{tabular}

Table 5 shows that Daemonorops draco found in the Harapan forest is mostly female plants. There is one female plant found near the river flow and also in the $10-20 \mathrm{~cm}$ soil layer found charcoal/a sign of burned land. This proves that there are several forest fires in the past.

Table 6 shows that the soil fertility in male plants of $D$. longipes is better than female plants. Because the soil structure of female plants has dust sand, while in male plants, it contains litter in $20-30 \mathrm{~cm}$ layer. This proves that the soil at male plant has been eroded/erosion because it is near the river flow and the litter was accumulated there. The female habitat near the slope is likely to erode the soil due to greater flooding and make the soil structure become sandy.

\section{Nutrient analysis on the habitat of Daemonorops spp in Harapan Forest}

Table 7 shows that the habitats of Daemonorops spp in Harapan Forest have a relatively low $\mathrm{pH}$ with a $\mathrm{pH}$ value of $\mathrm{H}+<5$ indicating that the soil is acidic. This low $\mathrm{pH}$ is due to the washing of base cations occurring from the upper layers to the deeper layers leaving the $\mathrm{H}+$ and $\mathrm{Al} 3+$ cations in the top layer which play a major role in soil acidity (Hong 2008). The low pH may cause some elements to become unavailable on the ground. CEC is an indicator of soil fertility, Cation Exchange Capacity in the above table varies from low to high with a value of 10.72 $\mathrm{me} / 100 \mathrm{~g}$ to $37.90 \mathrm{me} / 100 \mathrm{~g}$. The variability of CEC value is influenced by the low content of clay fraction in the area. According to Sukisno et al. (2011), high CEC value is also influenced by clay content, because the soil dominated by clay fraction has ion exchange capacity and holds high water, besides $\mathrm{pH}$ and organic matter can also influence it.

The spread of C-organic value is low to moderate with the range of $0.86 \%$ to $2.18 \%$ of this condition is because the soil in the location area is a forest with high rainfall and the decomposition rate of organic material is also high. In general, many forest areas filled with litter, litter or decaying foliage are naturally decomposition process into organic material that can increase soil fertility. Carbon is a food source of soil microorganisms, so that the presence of C-organic in the soil will stimulate the activity of microorganisms so as to increase the process of soil decomposition as well as reactions that require the help of microorganisms, e.g. dissolution $\mathrm{P}$, and $\mathrm{N}$ fixation. 
Table 7. Soil chemical parameters on the habitat of Daemonorops spp. in Harapan Forest

\begin{tabular}{lccccccc}
\hline \multicolumn{1}{c}{ Species } & $\mathbf{p H}$ & Al-dd & H-dd & CEC & C (\%) & N $(\%)$ & P $(\mathbf{p p m})$ \\
\hline Female D. draco & 4.7 & 3.37 & 0.74 & 26.28 & 2.03 & 0.162 & 6.75 \\
Female D. draco & 4.62 & 3.62 & 0.65 & 25.43 & 2.18 & 0.157 & 4.99 \\
Male D. draco & 4.7 & 5.48 & 1.03 & 9.35 & 1.91 & 0.152 & 4.99 \\
Male D. draco & 4.43 & 4.56 & 0.9 & 8.98 & 1.11 & 0.119 & 9.18 \\
Female D. didymophylla & 4.64 & 1.86 & 0.48 & 15.90 & 1.06 & 0.097 & 5.91 \\
Female D. didymophylla & 4.49 & 1.45 & 0.48 & 6.87 & 1.24 & 0.085 & 9.08 \\
Female D. didymophylla & 4.27 & 4.48 & 0.81 & 15.01 & 1.47 & 0.155 & 7.89 \\
Male D. didymophylla & 4.85 & 3.01 & 0.47 & 19.11 & 1.77 & 0.095 & 7.20 \\
Male D. didymophylla & 4.57 & 4.51 & 0.66 & 37.90 & 1.36 & 0.179 & 4.19 \\
Female D. longipes & 4.71 & 2.42 & 0.55 & 10.72 & 0.86 & 0.114 & 5.94 \\
Female D. longipes & 4.41 & 1.42 & 0.13 & 13.03 & 0.93 & 0.080 & 7.63 \\
Female D. longipes & 4.97 & 3.4 & 0.87 & 8.25 & 1.92 & 0.130 & 0.84 \\
Male D. longipes & 4.45 & 5.08 & 0.78 & 25.46 & 1.42 & 0.150 & 2.44 \\
Male D. longipes & 4.51 & 3.29 & 0.66 & 20.72 & 0.92 & 0.145 & 1.73 \\
\hline
\end{tabular}

Table 8. Correlation matrix from seven soil parameters

\begin{tabular}{lccccccc}
\hline & pH & AL_dd & H_dd & CEC & C & N & P \\
\hline pH & 1.000 & -0.093 & -0.129 & -0.066 & 0.478 & -0.047 & -0.401 \\
AL_dd & -0.093 & 1.000 & -0.019 & 0.301 & 0.411 & 0.776 & -0.305 \\
H_dd & -0.129 & -0.019 & 1.000 & 0.108 & -0.328 & 0.145 & -0.433 \\
KTK & -0.066 & 0.301 & 0.108 & 1.000 & 0.220 & 0.638 & -0.311 \\
C & 0.478 & 0.411 & -0.328 & 0.220 & 1.000 & 0.465 & -0.183 \\
N & -0.047 & 0.776 & 0.145 & 0.638 & 0.465 & 1.000 & -0.459 \\
P & -0.401 & -0.305 & -0.433 & -0.311 & -0.183 & -0.459 & 1.000 \\
\hline
\end{tabular}

Table 9. Results of KMO and Bartlett's Test

\begin{tabular}{llr}
\hline Kaiser-Meyer-Olkin Measure of Sampling Adequacy. & & 0.515 \\
Bartlett's Test of Sphericity & Approx. Chi-Square & 34.816 \\
& Df & 21 \\
& Sig. & 0.030 \\
\hline
\end{tabular}

Table 10. The results of calculating the variances of the principal components

\begin{tabular}{ccccccccc}
\hline Variant & Y1 & Y2 & Y3 & Y4 & Y5 & Y6 & Y7 \\
\hline Eigenvalue & 2.7434 & 1.5723 & 1.3316 & 0.6936 & 0.3654 & 0.1874 & 0.1063 \\
Proportion & 0.392 & 0.225 & 0.190 & 0.099 & 0.052 & 0.027 & 0.015 \\
Cumulative & 0.392 & 0.617 & 0.807 & 0.906 & 0.958 & 0.985 & 1.000 \\
\hline
\end{tabular}

Table 11. The principal components of seven chemical soil paramaters

\begin{tabular}{llllllll}
\hline Variable & PC1 & PC2 & PC3 & PC4 & PC5 & PC6 & PC7 \\
\hline pH & 0.129 & 0.525 & 0.580 & 0.085 & -0.058 & -0.586 & 0.131 \\
Al-dd & 0.465 & -0.029 & -0.315 & -0.550 & -0.204 & -0.391 & -0.432 \\
H-dd & 0.084 & -0.599 & 0.439 & -0.153 & 0.607 & -0.192 & -0.110 \\
CEC & 0.401 & -0.197 & -0.141 & 0.810 & -0.053 & -0.173 & -0.302 \\
C $(\%)$ & 0.370 & 0.538 & -0.048 & -0.019 & 0.597 & 0.404 & -0.226 \\
N $(\%)$ & 0.558 & -0.127 & -0.194 & -0.045 & 0.064 & -0.018 & 0.793 \\
P (ppm) & -0.389 & 0.138 & -0.558 & 0.091 & 0.472 & -0.523 & 0.114 \\
\hline
\end{tabular}




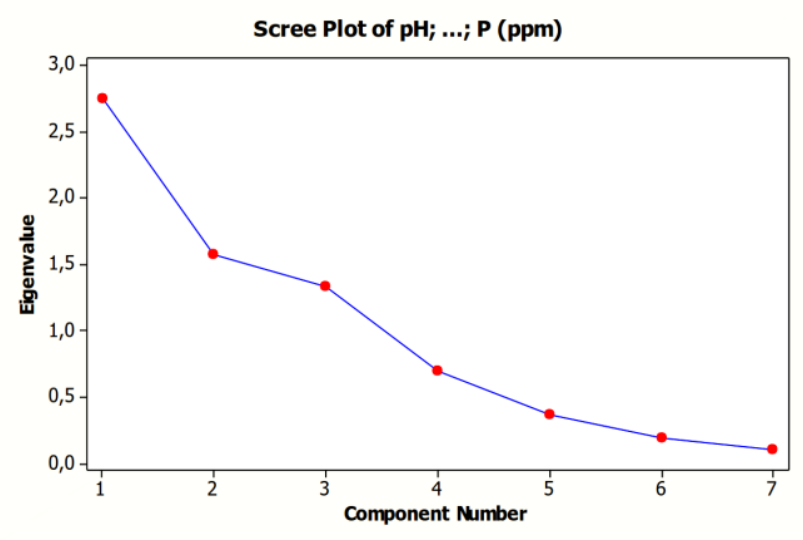

Figure 5. Scree plot of eigenvalue from seven variant components

The content of $\mathrm{N}$ is from very low to low ranging from $0.080 \%$ to $0.179 \%$. This is because generally, Daemonorops grow on the topography which has a steep slope to steep. The low $\mathrm{N}$ is suspected because $\mathrm{N}$ is easily lost through washing or evaporation.

Hardjowigeno (2003) explains that the process of loss of $\mathrm{N}$ present in the soil can be caused by the absorption of plants, used by microorganisms, $\mathrm{N}$ is still in the form of $\mathrm{NH} 4$ + which is bound by illite mineral so that cannot be used by plants, $\mathrm{N}$ is also in the form of NO3-which is easily washed by rainwater, and the condition of the land that is still inundated with drainage hunting and poor air fertilization can also occur denitrification process and also volatilize in the form of $\mathrm{NH}_{3}$ (ammonia). The content of $\mathrm{P}$ is less than $10 \mathrm{ppm}$ ranging from $0.84 \mathrm{ppm}$ to $9.18 \mathrm{ppm}$. This indicates that the habitats have low organic matter. The content of $\mathrm{P}$ in the soil is determined by organic matter and irrigation water and also the minerals found in the soil.

Correlation among seven soil variables can be seen in Table 8 . The results show that correlation among variables has values $<0.5$ and $>0.5$. This indicated that there are strong and weak correlations among those variables. To measure of sampling adequacy, the KMO and Barlett test were performed before continuing with Principal Component Analysis (PCA).

Table 9 shows the KMO value obtained is 0.515 (KMO value>0.5) which means that the correlation value between pairs of variables can be explained by other variables, so that the PCA analysis can be continued. Then the Bartlet test is used to see whether between variables have a correlation, the significance of this test can be seen from the sig Bartlet test value $<0.05$. In this data, a Bartlet test is obtained at 0.03 , which value $<0.05$ which means that between variables have a correlation. Because of the correlation between variables requires PCA to be done in order to reduce the variable without removing information from the variable.

Table 10 shows the eigenvalue, percentage, cumulative percentage. From the eigenvalue, it can be seen the variance of each variable. The variants of each major component are as follows: $\operatorname{Var}(\mathrm{Y} 1)=2.7434 \operatorname{Var}(\mathrm{Y} 2)=$
$1.5723 \operatorname{Var}(\mathrm{Y} 3)=0.13316 \operatorname{Var}(\mathrm{Y} 4)=0.6936 \operatorname{Var}(\mathrm{Y} 5)=$ $0.3654 \operatorname{Var}(\mathrm{Y} 6)=0.1874 \operatorname{Var}(\mathrm{Y} 7)=0.1063$. From the cumulative percentage value, the first three variables show $80.7 \%$ of the total variability. It states that 7 variables $(\mathrm{PH}$, Al-dd, H-dd, CEC, C (\%), N (\%) and P (ppm)) can be reduced to 3 new variables that can explain $80.7 \%$ of the total variability of seven variables. The reason for choosing the first 3 components is because these three components have an eigenvalue> 1. Based on the scree plot, the eigenvalue of variant component Y1, Y2 and Y2 can already explain the diversity of $80.7 \%$ (Figure 5).

Tabel 11 shows the principal components produced as follows: $\mathrm{PC} 1=0,129 \mathrm{PH}+0,465 \mathrm{Al}-\mathrm{dd}+0,084 \mathrm{H}-\mathrm{dd}+$ $0,401 \mathrm{KTK}+0,370 \mathrm{C}(\%)+0,558 \mathrm{~N}(\%)-0,389 \mathrm{P}(\mathrm{ppm}) ; \mathrm{Pc} 2$ $=0,525 \mathrm{PH}-0,029$ Al-dd-0,599 H-dd-0,197 KTK + 0,538 C $(\%)-0,127 \mathrm{~N}(\%)+0,138 \mathrm{P}(\mathrm{ppm}) ; \mathrm{PC} 3=0,580 \mathrm{PH}-0,315$ Al-dd + 0,439 H-dd-0,141 KTK-0,048 C (\%)-0,194 N (\%)$0,558 \mathrm{P}(\mathrm{ppm})$. Of the seven soil variables studied, after a factor analysis using the principal component analysis method, 3 factors were obtained: the first factor (PC1) was the most dominant factor having an eigenvalue of 2.77434 and was able to explain a total diversity of $39.2 \%$. This factor consists of the variable N. The second factor (PC2) with an eigenvalue of 1.5723 and able to explain the total diversity of $22.5 \%$. This factor consists of variable C. This factor is called a supporting factor. The third factor (PC3) with an eigenvalue of 1.3316 and able to explain the total diversity of $19 \%$. This factor consists of a variable $\mathrm{pH}$. This factor is called an additional factor. These three factors provide a cumulative proportion of $80.7 \%$, meaning that these three factors play a major role in the growth of Daemonorops spp in Harapan Forest.

In conclusion, three species of Daemonoropswere found in Harapan Rainforest, namely Daemonorops didymophylla, D. draco, and D. longipes. Daemonorops longipes has the highest population (18 clumps). The highest number of clumps was found in Hamparan Bato and Hamparan Batang Kapas areas. Daemonorops longipes and Daemonorops draco have female-biased sex ratios, while Daemonorops didymophylla has a male-biased sex ratio. Most clumps of Daemonorops species in Harapan Rainforest grow on the river banks which low organic matters. Soil chemical variables that most contribute to the growth of Daemonorops spp. in Harapan Forest are N, C and $\mathrm{pH}$.

\section{ACKNOWLEDGEMENTS}

We would like to send our grateful thanks to CRC 990 for funding this research, Restorasi Ekosistem Indonesia, our field guide Ferry and Raju. Also to our assistant Ari Setiawan, Mayningsih, Muhamad Lunas and Harun al Rasyid.

\section{REFERENCES}

Asra R, Syamsuardi, Mansyurdin, Witono JR. 2012. Rasio Seks Jernang (Daemonorops draco (Willd.) Blume) Pada Populasi Alami Dan Budidaya: Implikasi Untuk Produksi Biji. Bot Gard Bull 15 (1): 1-9. 
Asra R. 2013. Diversitas Dragon's Blood Palm (Daemonorops spp.) di hutan Sekunder Jambi. BioETI 1 (3): 153-157.

Asra R, Syamsuardi, Mansyurdin, Witono JR. 2014. The study of genetic diversity of Daemonorops draco (Palmae) using ISSR markers. Biodiversitas 15 (2): 109-114.

Balai Informasi Kehutanan Provinsi Jambi. 2009. http: //infokehutananjambi.or.id.Accessed 2 January 2009.

Cavallo P, Proto MC, Patruno C, Del Sorbo A, Bifulco M. 2008. The first cosmetic treatise of history.A female point of view. Intl J Cosmet Sci 30: $79-86$.

Ciccarese L, Mattson A, Pettenella D. 2012. Ecosystem Services From Forest Restoration: Thinking Ahead. New For 43: 543-560.

Dupont YL, Kato M. 1999. Sex ratio variation in dioecious plant species: A comparative ecological study of six species of Lindera (Lauraceae). Nordic J Bot 19: 529-540.

Gupta D, Bleakley B, Gupta RK. 2007. Dragons's blood: botany, chemistry and therapeutic uses. J Ethnopharmacol 115: 361-380.

Hardjowigeno S. 2003.Ilmu Tanah. Akademika Pressindo, Jakarta [Indonesian]

Harrison RD, Swinfield T. 2015. Restoration of logged humid tropical forest: An experimental program at Harapan Rainforest, Indonesia. Trop Conserv Sci 8 (1): 4-16.

Hong TK. 2008. Principles of Soil Chemistry.2nd Ed. Marse, Dekker Inc, New York.

Lee YF. 1995. Genetic and Ecological Studies Relevant to the Conservation and Management of some Bornean Calamus Species. [Dissertation]. University of Aberdeen, Scotland.

Mairida D, Muhadiono, Hilwan I. 2016. Ethnobotanical Study of Rattans on Suku Anak Dalam Community in Bukit Duabelas Nasional Park. Biosaintifika 8 (1): 64-72.

Pearson J. 2002. Dragon's Blood. The Horticulturist 11 (2).

Piozzi F, Passsannanti S, Paternostro MP. 1974. Diterpenoid exudate acids of Daemonorops draco. Phytochemistry 13: 2331-2233.
$\mathrm{R}$ Core Team. 2018. R: A language and environment for statisticalcomputing. R Foundation for Statistical Computing, Vienna, Austria.

Rottenberg A.2000. A field survey of dioecious plants in Israel: sex ratio in seven rare species. Bot J Linn Soc 134: 439-442.

Sulasmi IS, Nisyawati, Purwanto Y, Fatimah S. 2012a. Jernang Rattan (Daemonorops draco) Management by AnakDalamTribe in Jebak Village, Batanghari, Jambi Province. Biodiversitas 13: 151-160.

Sulasmi IS, Nisyawati, Purwanto Y, Fatimah S. 2012b. The population of Jernang rattan (Daemonorops draco) in Jebak Village, Batanghari District, Jambi Province, Indonesia. Biodiversitas 13 (4): 205-213.

Snedecor GW, Cohran WG. 1989. Statistical Methods. 8th ed. Iowa State University Press, Ames, Iowa.

Soemarna Y. 2009. Budidaya rotan jernang (Daemonorops draco Willd.). J Litbang Kehutanan Bogor 2 (3): 5-10. [Indonesian]

Stehlik I, Barrett SC. 2005.Mechanisms governing sex-ratio variation in dioecious Rumex nivalis. Evolution 59: 814-825.

Sukisno, Hindarto KS, Hasanuddin, Wicaksono AH. 2011. Pemetaan Potensi dan status Kerusakan Tanah untuk Mendukung Produktifitas Biomassa di Kabupaten Lebong. Program Studi Ilmu Tanah, Fakultas Pertanian, Universitas Bengkulu, Bengkulu. [Indonesian]

Thomson GE. 2007. The Health Benefits of Traditional Chinese Plant Medicines: Weighing the Scientific Evidence. Rural Industries Research and Development Corporation, Australian Government.

Waluyo TK. 2012. Teknik Ekstraksi Tradisional dan Analisis Sifat-Sifat Jernang Asal Jambi. Jurnal Penelitian Hasil Hutan 26 (1): 30-40. [Indonesian]

Waluyo TK. 2013. Perbandingan sifat fisiko-kimia 5 jenis jernang (Comparative study on physico-chemical properties of 5 dragon's blood species). Penelitian Hasil Hutan 31 (2): 141-150. [Indonesian]

Yamani A. 2010. Analisis kadar hara makro dalam tanah pada tanaman agroforestri di Desa Tambun Raya Kalimantan Tengah. Jurnal Hutan Tropis 11 (30): 37-46. [Indonesian] 